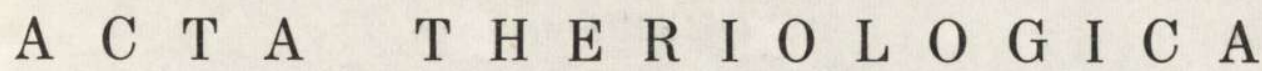 \\ VOL. $18,16: 289-311$ \\ BIAEOWIEŻA \\ August, 1973
}

BISONIANA LIII.

Franciszek K OBR Y N C Z K \& Henryk KOBR Y Ñ

\section{Postembryonic Growth of Bones of the Autopodia in the European Bison}

[With 16 Tables]

\begin{abstract}
The postembryonic development of the bones of the autopodial parts of the extremities was traced in 70 European bison of both sexes. The hydrometric test for defining the size of bones was used in these studies. It was found that the bones of the autopodial parts in the European bison are subject to constant changes during postembryonic development, and that although these changes are mainly progressive in character, they may often be regressive. Their occurrence is influenced by, in addition to the animals' age, the musculature of the skeleton and the topographic vicinity of the various bones. The great majority of bones in males have a greater mass than the corresponding bones in females, and an addition they grow more intensively up to the age of 12 years in males than they do in females. Over this age increase in bone mass is negligible in males, whereas in females it is still fairly considerable.
\end{abstract}

\section{INTRODUCTION}

The majority of researches have used the linear measurement method given by D u e r s t (1926) in examination of the skeleton of the European bison, this including studies by such authors as Koch (1932), J anicki (1938), J uśko (1953), Roskosz (1962), Empel (1962), Empel \& Roskosz (1963), Sokolov (1971), Kobryń (1972), Kobryńczyk (1972), Radomski (1972), Roskosz (1972).

This method does not, however, always give a correct picture of the size of the various bones which are, of course unshaped, blocks. It would appear that the linear measurement method is particularly inaccurate in studies on relatively small bones, which include the majority of the bones of the autopodial parts of the extremities.

The authors have aimed at tracing the post-embryonic development of the bones of the autopodial parts of the European bison's extremities, taking the bulk of these bones as the basis for discussion. 
Table 1

Comparison of material.

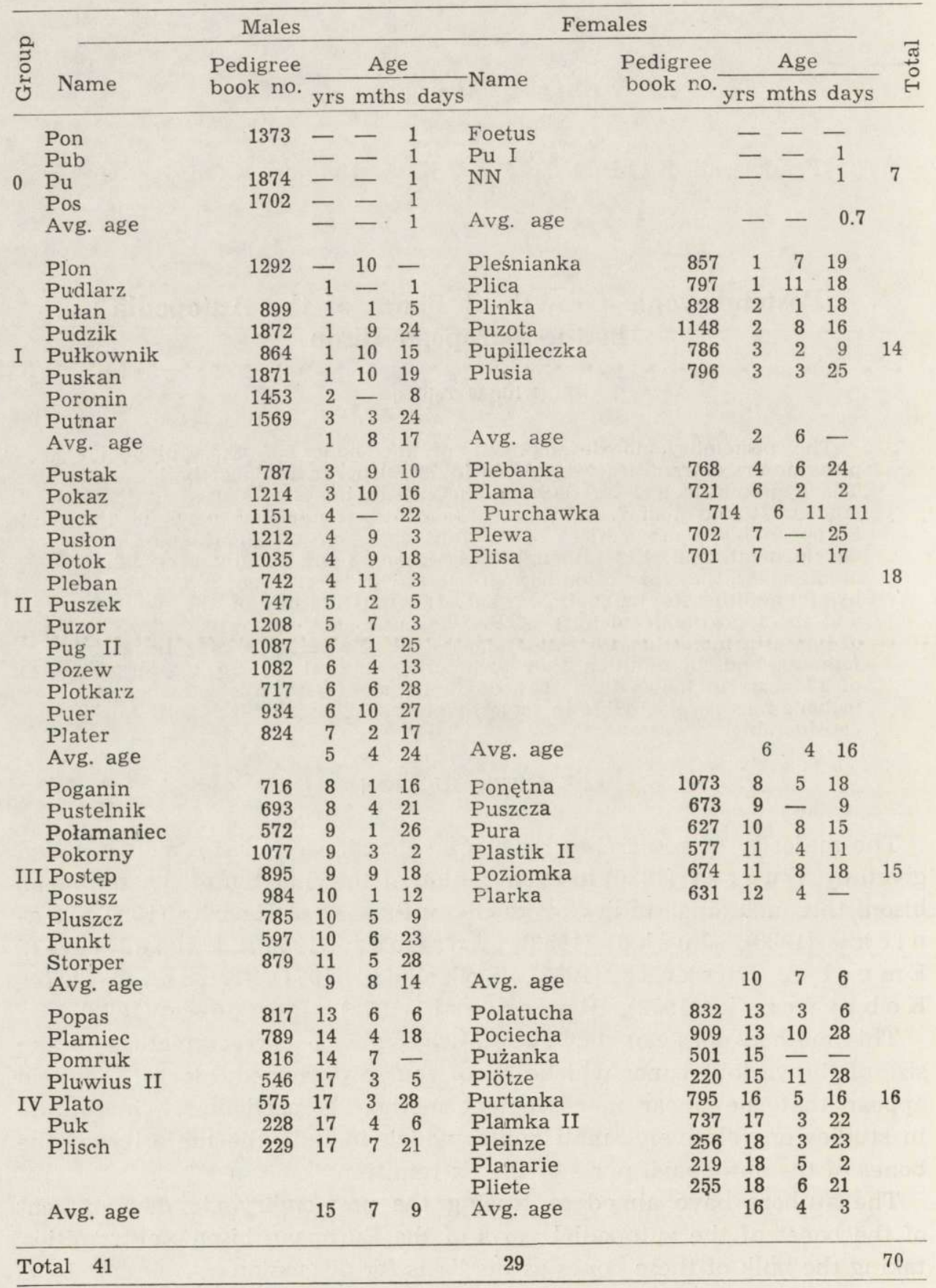




\section{MATERIAL AND METHODS}

Studies were on the bones of the autopodial parts of the extremities in 70 European bison, diving the material under observation into 5 groups, as was done in the study by Empel \& Roskosz (1963), Table 1. The age of the individuals examined was established by reference to the European Bison Pedigree Book (Ż a bi ń s k i, 1947-1965).

As the material was incomplete the following components of the skeleton of the autopodia were not taken into consideration: os metacarpale $V$, os metatarsale II, ossa sesamoidea phalangum proximalium, ossa sesamoidea phalangum distalium. In addition the skeleton of the recently found regressive ossa digitorum II et $V$ (Kobryńczuk, 1972, Radomski, 1972) was also omitted.

Material from the skeletons of the left manus and left pes was examined When defining the bulk of the phalanges the arithmetical average of bulk for the corresponding phalanges of both digits $I I I$ and $I V$ was taken into consideration, and thus differences in size of the corresponding phalanges of the two digits were not taken into account.

Measurements of bulk were made on the basis of the hydrometric test for defining the size of a bone, given by Roskosz et al. (1966), which roughly speaking consists in weighing the given unit twice. The first mass $\left(a_{1}\right)$ is obtained by weighing the bone in the normal way, e.g. using an analytical balance. The second mass $\left(\mathrm{a}_{2}\right)$ is obtained by weighing an object immersed in water. In accordance with the law of Archimedes the bulk of the bone studied (V) will be equal to the difference between the two masses

$$
V=a_{1}-a_{2}
$$

Use was made in further studies of the arithmetical averages $(\bar{x})$ of bulk of the various bones calculated for the corresponding groups. Standard deviation (s) and coefficient of variation $(v)$ are given for groups consisting of more than 5 individuals. Coefficients of growth in bones of the parts examined were also calculated by the method given by Davletova (1960) as were increases in percentages of bone bulk between the different groups. Calculation was also made of the percentages formed by the various bones of the structure of a given sub-segment of the autopodium and also the percentages represented by the various sub-segments in forming the whole autopodium.

Latin terminology was based on Nomina Anatomica Veterinaria (1968).

\section{RESULTS}

\section{Autopodium anterius}

\subsection{Basipodium - ossa carpi}

Among the six bones of this sub-segment of the skeleton of the manus in the European bison, os carpi intermedium was found to have the greatest mass in embryos and newborn bison of both sexes (Table 2). In the other groups, however, os carpale $I I+I I I$ same first in order of bulk. The second place in this order was occupied in embryos and 


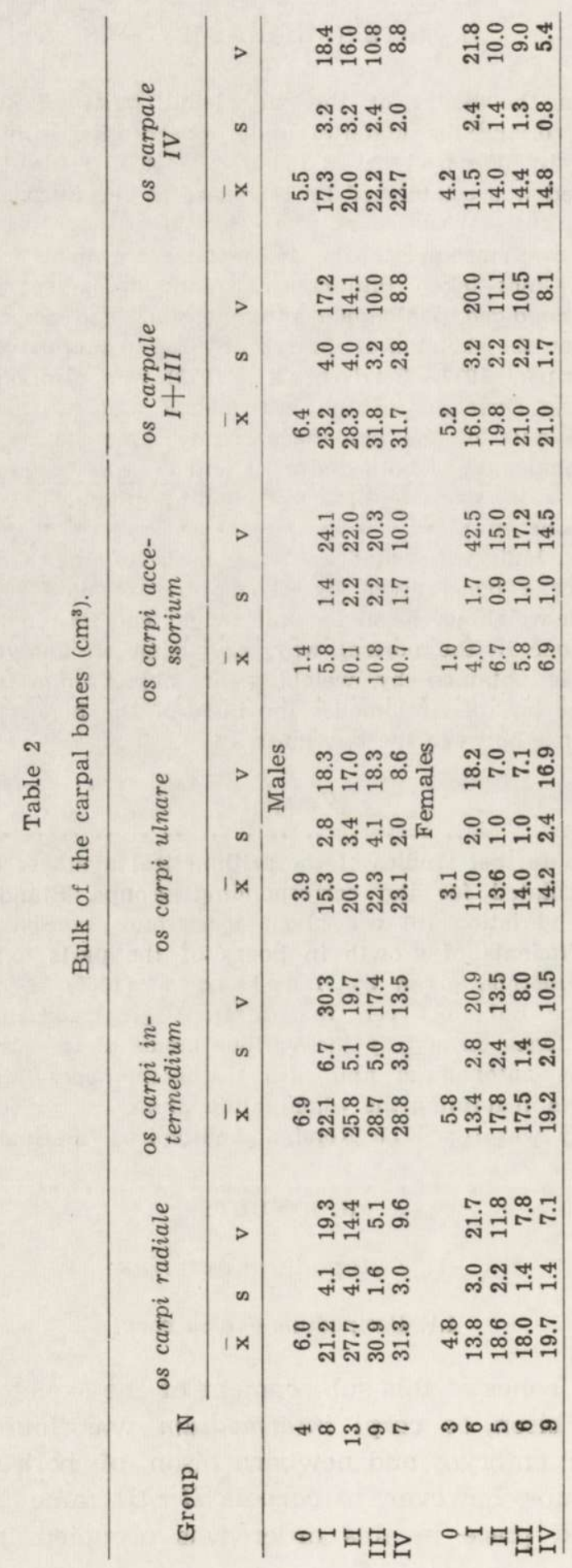


newborn animals by os carpale II+III, in males of group I - os carpi intermedium, while in groups II-IV of males and I-IV of femalesos carpi radiale. The third bone in order of size is os carpi radiale in groups 0 -I males and 0 of females, while in groups II-IV of males and I-IV of females - os carpi intermedium. The fourth in order of size is os carpale IV in all groups of females and groups 0 -II of males, and in the remaining groups of males (III-IV) - os carpi ulnare. Fifth place in respect of bulk is occupied in all females and males in groups 0 -II by os carpi ulnare, and by os carpale IV in the other groups of males (III-IV). The final, sixth place is occupied in all European bison by os carpi accessorium.

The bone which grows most intensively in the carpus is os carpi accessorium in males (Table 7), while os carpi ulnare comes second in this respect, os carpi radiale third, os carpale $I I+I I I$ fourth, os carpi intermedium fifth and os carpale IV the sixth and final place. The same order is found in the case of females, except for the fifth place, which is occupied by os carpale $I V$, and the sixth place, occupied by os carpi intermedium.

All the growth coefficients for the carpal bones are higher in males than in females (Table 7).

Increases expressed in percentages of the bulk of these bones are particularly great in group I of males. These increases become gradually smaller with the passage of time, and reach their positive minimum in the oldest group, or even fall to negative values (Table 9). The distribution of percentage increases in the bulk of the various carpal bones during postembryonic development is slightly different in females than in males. Although these increases are considerable in females of group I, they are not as great as in the corresponding males, whereas in the oldest females increase in the bone bulk of these units is far greater than in males (Table 9). Group III females, in which some of the carpal bones exhibit either negative percentage increases (ossa carpi: radiale, intermedium and accessorium) or are expressed in negligibly small positive figures (remaining carpal bones) are remarkable. We can thus observe certain crises in the bone-forming processes of these bone units in this group of females.

The percentages formed by the various components of the structure of the bony framework of the carpus change with age (Table 11). In certain bones this percentage tends to increase, and in others decrease. Among the first are ossa carpi: radiale, ulnare, accessorium; among the second os carpi intermedium and os carpale IV. Os carpale II III forms a more or less uniform percentage of the structure of the basipodium throughout the whole of the animal's life. 
Bones of the antebrachial row of the carpus together form $61.7 \%$ of the whole of the bony framework in the youngest males, and therefore this figure is $38.8 \%$ for the metacarpal row. In the oldest males this figure is $63.3 \%$ for the antebrachial row and $36.7 \%$ for the metacarpal row. In the youngest females the antebrachial row forms $60.0 \%$ and the metacarpal row $39.4 \%$ of the mass of the whole of the carpal skeleton, whereas in the oldest females these figures are respectively $62.6 \%$ and $37.4 \%$. Thus in both cases the antebrachial row is characterized by greater increase of bone mass during postembryonic development than the metacarpal row. This fact is further confirmed by the higher growth coefficients for the antebrachial row (5.7-males, 4.1 - females) than for the metacarpal row (4.6-males, 3.8 -females).

Table 3

Bulk of the metacarpal and metatarsal bones $\left(\mathrm{cm}^{3}\right)$.

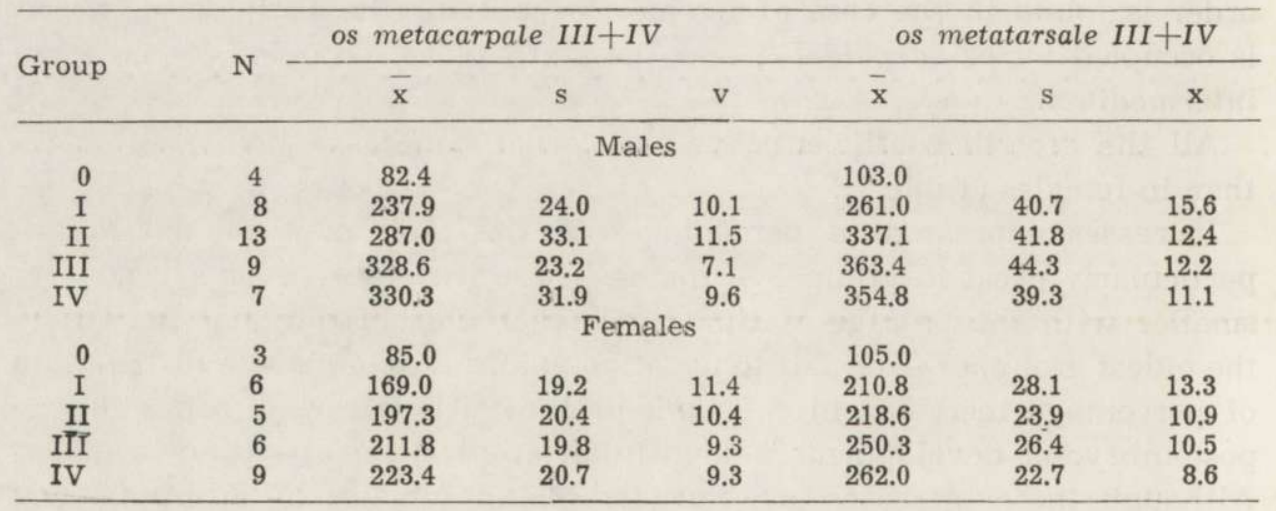

The participation of the carpal bones in the structure of the skeleton of the manus (Table 15) is the smallest in comparison with the metapodium and acropodium, and is almost uniform throughout the entire life span in males, and increases by about $2 \%$ in females.

Comparison of growth coefficients (Table 7) shows that the carpus increases its mass during the animal's life span to a greater extent than the metacarpal bones, but to a lesser degree than the skeleton of the digit of the manus.

\subsection{Metapodium - ossa metacarpi}

The bulk of the metacarpal bones (Table 3) in group 0 of females is exceptionally greater than in the corresponding males, but in the other group it is decidedly greater in the latter. Consequently the growth coefficient of these bones in males is outstandingly greater than in 
females (Table 7), but these coefficients are the smallest in the case of both sexes of those observed in the whole of the bone material of the manus. The metapodium forms the greatest percentage of the structure of the autopodium (Table 15), and this percentage exhibits considerable tendency to decrease during the course of the animal's life; in the oldest groups it is almost the same as that of the acropodium.

\subsection{Acropodium - ossa digiti manus}

Among the three phalanges of the manus it is phalanx proximalis which has by far the greatest bulk (Table 4). The second in this order in groups 0-I of males and groups I-II of females is phalanx media, which is exceeded in the older age groups by phalanx distalis. Consequently the third place in this order of size in groups $0-\mathrm{I}$ of males and 0 - II of females in phalanx distalis, and in the older groups phalanx media.

Phalanx distalis is distinguished by far the highest growth coeficient (Table 7), and incidentally this is the greatest growt coefficient recorded in the whole of the study material. The second place in order of growth rate is occupied by phalanx media, the third by phalanx proximalis.

Phalanx distalis, in the comparison with the other two, is characterized in all groups by the greates percentages of increase in bone mass (Table 9). An exception to this is formed only by group IV of females, where maximum increase is observed for phalanx media. In turn the smallest percentages of increase in bulk is exhibited in both sexes of group I by phalanx proximalis, in groups II-III by phalanx media and in group IV by phalanx proximalis. When increases in percentages of the mass of these components of the digital structure are considered it is found that in group I they are far greater in males than in females. The revers is the case in groups IV, where the phalanges of the females, in particular phalanx proximalis and media, are characterized by greater increases in mass than in the case with males. Phalanx proximalis and phalanx media in representatives of group III are characterized by slow growth rate, as is shown by the smaller percentage increases of their bone mass than in group IV (Table 9).

The greates percentage of the structure of the digital skeleton (Table 12) is formed by phalanx proximalis, and the lowest percentage by phalanx distalis, the percentage of which in the digital structure increases successively though the whole of animal's life span at the expense of the other two phalanges (Table 12).

All phalanges in males in the different age groups are greater than those of the corresponding phalanges in females. 


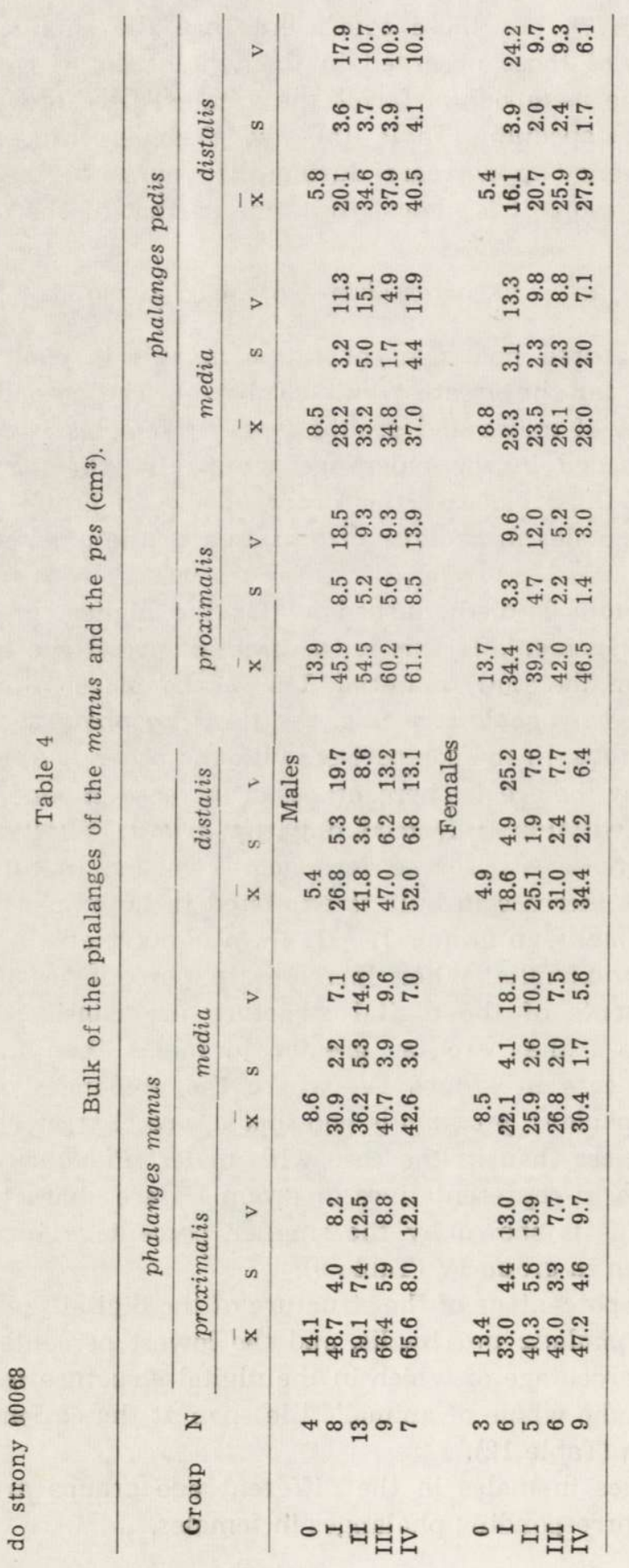




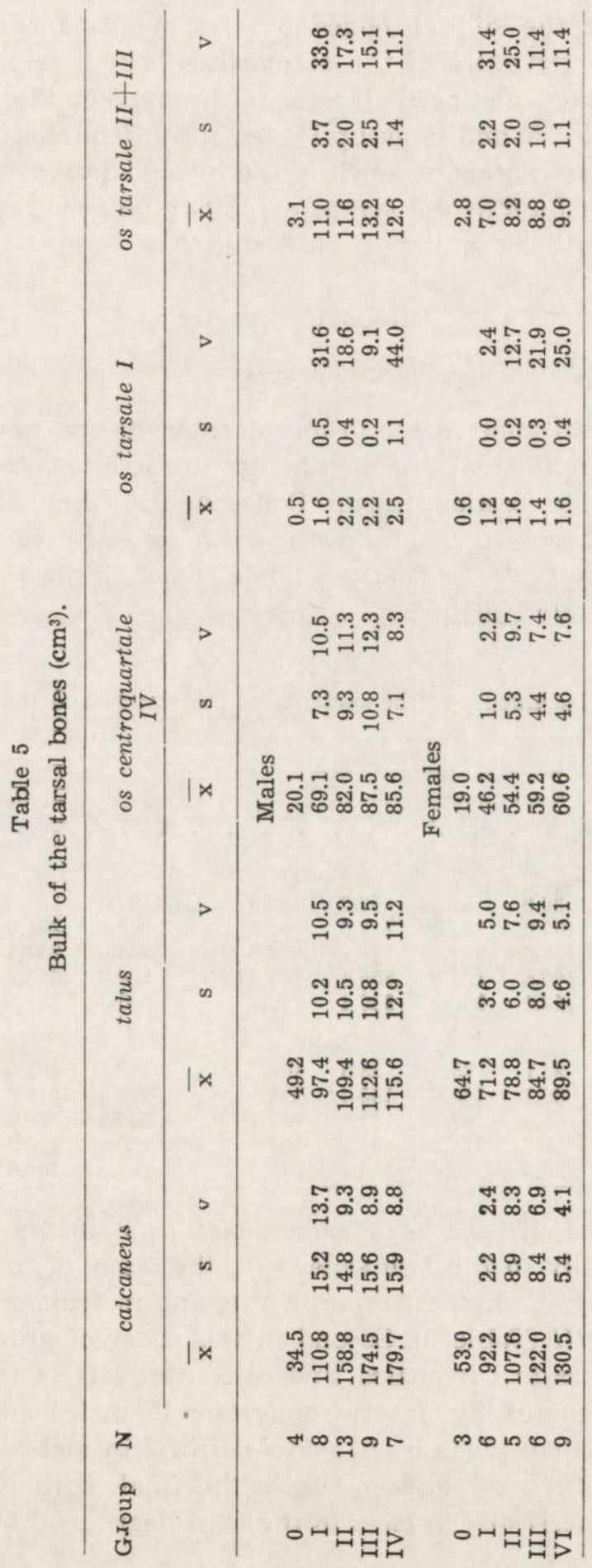


Taken together the digital bones of the manus form the smallest percentage of the structure of the autopodium, but it is more important that this percentage distinctly increases throughout the whole of the animal's life (Table 15) and in group IV females it is already exceptionally greater than the percentage formed by the metapodium.

In all the acropodium of the manus exhibits a higher growth coefficient than the basipodium and metapodium (Table 7).

\section{Autopodium posterius}

\subsection{Basipodium - ossa tarsi}

The largest tarsal bone in the group of embryos and newborn animals of both sexes is the talus (Table 5), whereas in the other groups calcaneus attains considerable predominance. Consequently the second place in order of mass is occupied in group 0 of both sexes by calcaneus, and in the other group by talus. Os centroquartale comes third, os tarsale II+III fourth, and os tarsale I fifth.

Table 6

Bulk of the subsegments of the skeleton of the manus and the pes $\left(\mathrm{cm}^{3}\right)$.

\begin{tabular}{|c|c|c|c|c|c|c|c|c|c|}
\hline \multirow[b]{2}{*}{ Group } & \multirow[b]{2}{*}{$\mathrm{N}$} & \multicolumn{4}{|c|}{ manus } & \multicolumn{4}{|c|}{ pes } \\
\hline & & $\begin{array}{r}\text { basi- } \\
\text { podium }\end{array}$ & $\begin{array}{l}\text { meta- } \\
\text { podium }\end{array}$ & $\begin{array}{c}\text { acro- } \\
\text { podium }\end{array}$ & Total & $\begin{array}{l}\text { basi- } \\
\text { podium }\end{array}$ & $\begin{array}{l}\text { meta- } \\
\text { podium }\end{array}$ & $\begin{array}{l}\text { acro- } \\
\text { podium }\end{array}$ & Total \\
\hline \multicolumn{10}{|c|}{ Males } \\
\hline 0 & 4 & 30.0 & 82.4 & 56.2 & 168.6 & 107.5 & 103.0 & 56.2 & 266.7 \\
\hline I & 8 & 105.0 & 237.9 & 212.8 & 555.7 & $2 \overline{89} .8$ & 261.0 & 188.2 & 739.0 \\
\hline II & 13 & 132.0 & 287.0 & 274.2 & 693.2 & 364.0 & 337.1 & 244.6 & 945.7 \\
\hline III & 9 & 146.6 & 328.6 & 308.4 & 783.6 & 389.9 & 363.4 & 265.6 & 1018.9 \\
\hline IV & 7 & 148.4 & 330.3 & 320.4 & 799.1 & 395.9 & 354.8 & 277.0 & 1027.7 \\
\hline \multicolumn{10}{|c|}{ Females } \\
\hline 0 & 3 & 24.1 & 85.0 & 53.6 & 162.7 & 140.1 & 105.0 & 55.6 & 300.7 \\
\hline I & 6 & 69.7 & 169.0 & 153.4 & 392.1 & 218.0 & 210.8 & 147.6 & 576.4 \\
\hline II & 5 & 89.8 & 197.3 & 182.6 & 469.7 & 250.4 & 218.6 & 166.8 & 635.8 \\
\hline III & 6 & 90.7 & 211.8 & 201.6 & 504.1 & 276.0 & 250.3 & 188.0 & 714.3 \\
\hline IV & 9 & 95.8 & 223.4 & 223.8 & 543.0 & 291.8 & 262.6 & 204.8 & 759.2 \\
\hline
\end{tabular}

The rate of growth of the various bony components of the tarsus differs diametrically in the two sexes. In the case of males calcaneus is distinguished by the highest growth rate, and in females unexpectedly by os tarsale $I I+I I I$ (Table 8). Second in this order of growth coefficient value comes os tarsale $I$ in males, and os controquartale in females. The third place is occupied by os centroquartale in males and os tarsale $I$ in females, and fourth place by os tarsale II $+I I I$ in males, and calcaneus in females. In both sexes talus occupies the final, fifth place, and it is therefore a unit increasing in mass to the least degree. 


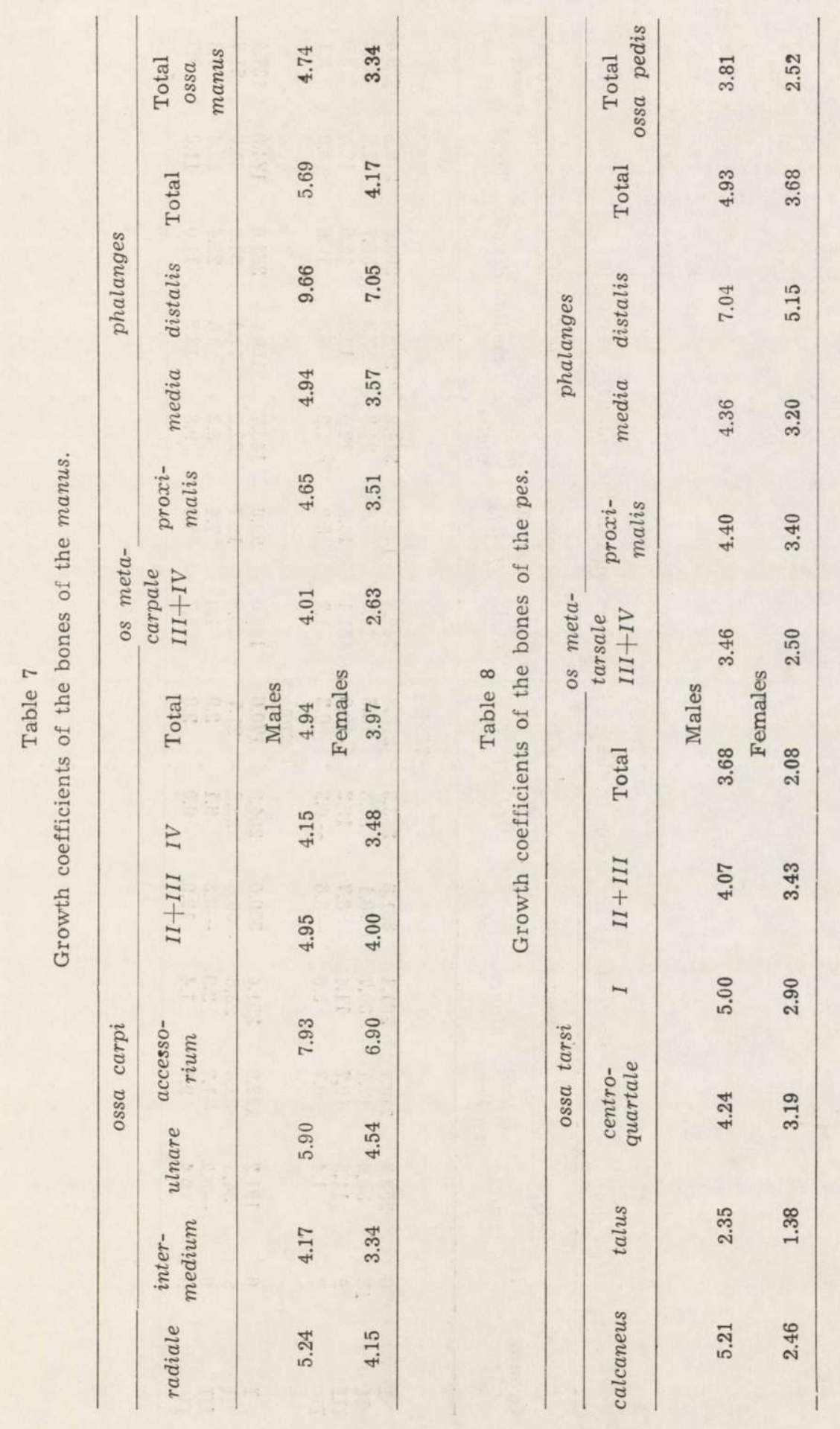




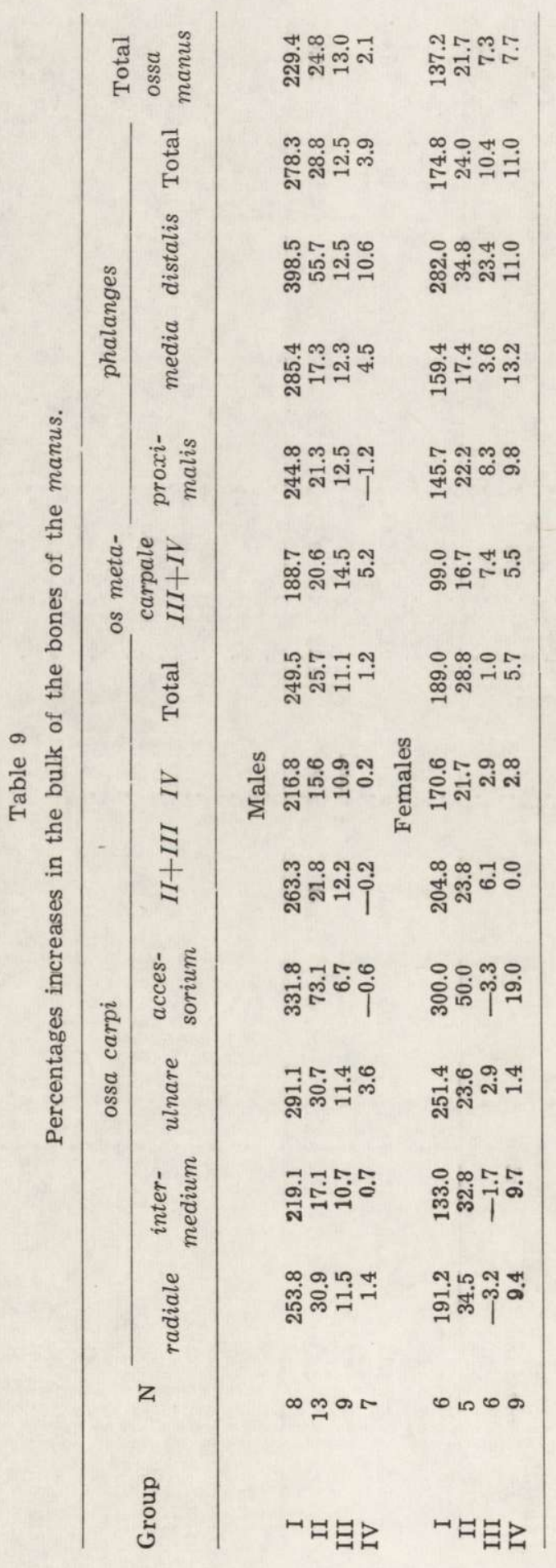




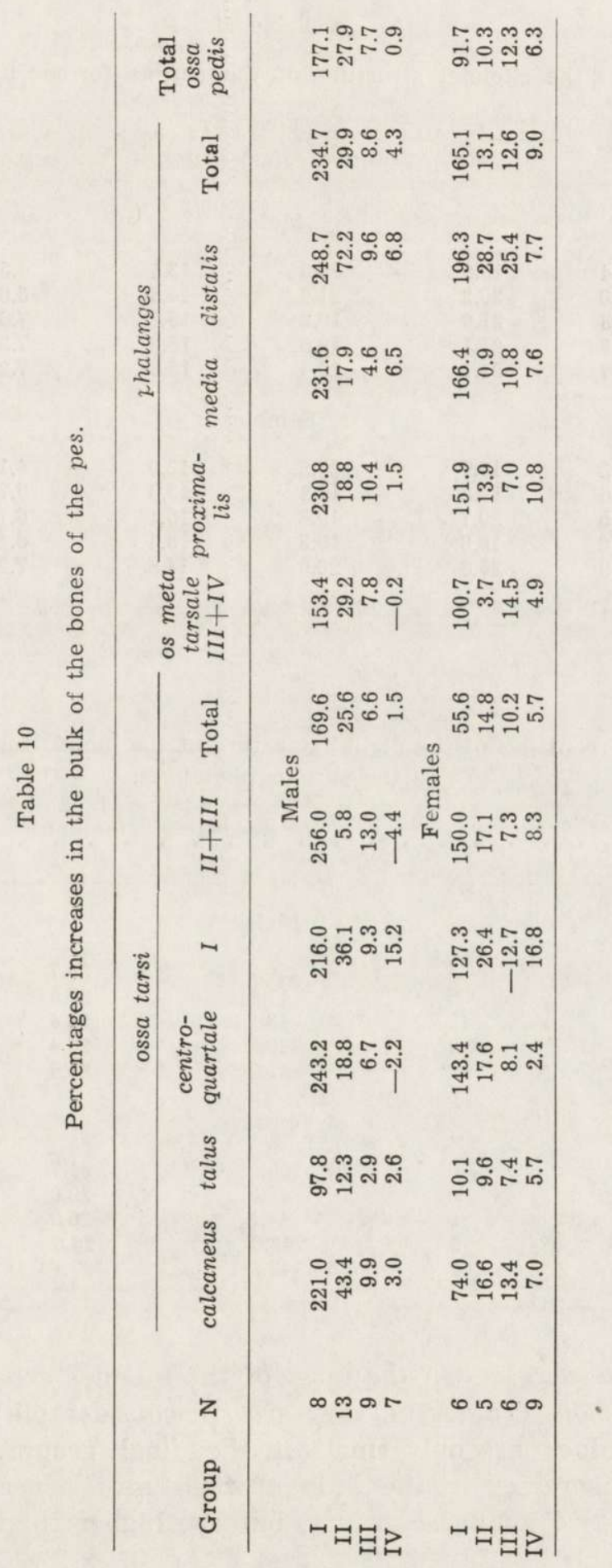


Table 11

Percentages of the skeletal structure of the carpus formed by the various biones.

\begin{tabular}{|c|c|c|c|c|c|c|c|}
\hline \multirow{2}{*}{ Group } & \multirow{2}{*}{$\mathrm{N}$} & \multicolumn{4}{|c|}{ os carpi } & \multicolumn{2}{|c|}{ os carpale } \\
\hline & & radiale & intermedium & ulnare & accessorium & $I I+I I I$ & $I \Lambda$ \\
\hline \multicolumn{8}{|c|}{ Males } \\
\hline 0 & 4 & 19.9 & 23.0 & 13.1 & 4.5 & 21.3 & 18.2 \\
\hline I & 8 & 20.2 & 21.0 & 14.5 & 5.6 & 22.2 & 16.5 \\
\hline$\overline{\mathrm{II}}$ & 13 & 21.0 & 19.8 & 15.2 & 7.6 & 21.5 & 15.2 \\
\hline III & 9 & 21.1 & 19.6 & 15.2 & 7.3 & 21.7 & 15.1 \\
\hline IV & 7 & 21.1 & 19.4 & 15.6 & 7.2 & 21.4 & 15.3 \\
\hline \multicolumn{8}{|c|}{ Females } \\
\hline 0 & 3 & 19.7 & 23.8 & 13.0 & 4.1 & 21.8 & 17.6 \\
\hline I & 6 & 19.8 & 19.2 & 15.8 & 5.7 & 23.0 & 16.5 \\
\hline II & 5 & 20.7 & 19.8 & 15.1 & 6.7 & 22.1 & 15.6 \\
\hline III & 6 & 19.8 & 19.3 & 15.4 & 6.4 & 23.2 & 15.9 \\
\hline IV & 9 & 20.6 & 20.0 & 14.8 & 7.2 & 21.9 & 15.5 \\
\hline
\end{tabular}

Table 12

Prcentages of the digital structure of the manus formed by the various phalanges.

\begin{tabular}{ccccc}
\hline Group & N & $\begin{array}{c}\text { phalanx } \\
\text { proximalis }\end{array}$ & $\begin{array}{c}\text { phalanx } \\
\text { media }\end{array}$ & $\begin{array}{c}\text { phalanx } \\
\text { distalis }\end{array}$ \\
\hline & Males & & \\
I & 4 & 50.2 & 30.7 & 25.2 \\
II & 8 & 47.8 & 29.0 & 30.5 \\
III & 13 & 43.1 & 26.4 & 30.5 \\
IV & 9 & 43.1 & 26.4 & 32.4 \\
& 7 & 41.0 & 26.6 & 18.2 \\
IV & & & & 25.3 \\
II & 3 & Females & & 27.6 \\
III & 6 & 50.1 & 31.7 & 30.8 \\
IV & 5 & 44.8 & 29.9 & 30.7 \\
\hline
\end{tabular}

Percentage increases in the mass of these bones are particularly high in group I males (Table 10); they are stil considerable in group II also, but such values are only small in the final groups. In females the percentage increases in the bulk of the tarsal bones are lower than in males in two youngest groups, but are higher than in males in trie 
Table 13

Percentages of the digital structure of the pes formed by the various phalanges.

\begin{tabular}{ccccc}
\hline Group & N & $\begin{array}{c}\text { phalanx } \\
\text { proximalis }\end{array}$ & $\begin{array}{c}\text { phalanx } \\
\text { media }\end{array}$ & $\begin{array}{c}\text { phalanx } \\
\text { distalis }\end{array}$ \\
\hline & Males & & \\
I & 4 & 49.3 & 30.3 & 20.4 \\
I & 8 & 48.7 & 30.0 & 2.3 \\
II & 13 & 44.6 & 27.2 & 28.2 \\
IV & 9 & 45.3 & 26.2 & 28.5 \\
& 7 & 44.1 & 26.7 & 29.2 \\
& & & & \\
I & & Females & & \\
II & 3 & 49.1 & 31.4 & 19.5 \\
III & 6 & 46.7 & 31.6 & 21.7 \\
IV & 5 & 47.0 & 29.2 & 24.8 \\
& 6 & 44.7 & 27.7 & 27.6 \\
\hline
\end{tabular}

Table 14

Percentages of the skeletal structur of the tarsus formed by the various subsegments.

\begin{tabular}{|c|c|c|c|c|c|c|}
\hline Group & $\mathrm{N}$ & calcaneus & talus & $\begin{array}{c}\text { os cent roquar- } \\
\text { tale }\end{array}$ & $\begin{array}{c}\text { os tarsale } \\
I\end{array}$ & $\begin{array}{l}\text { os tarsale } \\
\qquad I+I I I\end{array}$ \\
\hline \multicolumn{7}{|c|}{ Males } \\
\hline 0 & 4 & 32.1 & 45.8 & 18.7 & 0.5 & 2.9 \\
\hline I & 8 & 38.2 & 33.6 & 23.8 & 0.5 & 3.9 \\
\hline II & 13 & 43.6 & 30.0 & 22.5 & 0.6 & 3.3 \\
\hline III & 9 & 44.8 & 28.9 & 22.4 & 0.6 & 3.3 \\
\hline IV & 7 & 45.4 & 29.2 & 21.6 & 0.6 & 3.2 \\
\hline \multicolumn{7}{|c|}{ Females } \\
\hline 0 & 3 & 37.8 & 46.2 & 13.6 & 0.4 & 2.0 \\
\hline I & 6 & 42.3 & 32.7 & 21.2 & 0.6 & 3.2 \\
\hline II & 5 & 42.9 & 31.5 & 21.7 & 0.6 & 3.3 \\
\hline III & 6 & 44.2 & 30.7 & 21.4 & 0.5 & 3.2 \\
\hline IV & 9 & 44.7 & 30.7 & 20.8 & 0.6 & 3.2 \\
\hline
\end{tabular}

two oldest groups. The general harmony of growth of the tarsal bones in group III females is disturbed by os tarsale I (Table 10), the increase in mass of which is exceptionally low. A similar but less striking situation can be observed in males also. Os tarsale II+III in group II males, which only increases its mass to a very slight extent in comparison with group I (difference of almost 4 years) is also surprising. The most remarkable finding, however, when analysing the bones of this part of the pes, is the very small increase in mass of the talus in group I females (Table 10) 
Table 15

Percentages of the skeletal structure of the anterior autopodium formed by the various subsegments.

\begin{tabular}{ccccc} 
Group & $\mathrm{N}$ & ossa carpi & $\begin{array}{c}\text { os metacarpale } \\
I I I+I V\end{array}$ & ossa digitorum \\
\hline & & Males & & \\
O & 4 & 17.8 & 48.8 & 33.4 \\
I & 8 & 18.9 & 42.8 & 39.5 \\
II & 13 & 19.1 & 41.4 & 39.4 \\
III & 9 & 18.7 & 41.9 & 40.1 \\
IV & 7 & 18.6 & 41.3 & 33.0 \\
& & Females & & 38.1 \\
I & 3 & 14.8 & 52.2 & 38.9 \\
II & 6 & 18.1 & 43.8 & 40.0 \\
III & 5 & 19.1 & 42.0 & 41.3 \\
IV & 6 & 18.0 & 42.0 & \\
\hline
\end{tabular}

Table 16

Percentages of the skeletal structure of the posterior autopodium formed by the various subsegments.

\begin{tabular}{|c|c|c|c|c|}
\hline Group & $\mathrm{N}$ & ossa tarsi & $\begin{array}{c}\text { os metacarpale } \\
I I I+I V\end{array}$ & ossa digitorum \\
\hline & & Males & & \\
\hline 0 & 4 & 40.3 & 38.6 & 21.1 \\
\hline I & 8 & 39.2 & 35.3 & 25.5 \\
\hline II & 13 & 38.5 & 35.6 & 25.9 \\
\hline III & 9 & 38.3 & 35.7 & 26.0 \\
\hline \multirow[t]{2}{*}{ IV } & 7 & 38.5 & 34.5 & 27.0 \\
\hline & & Females & & \\
\hline 0 & 3 & 46.6 & 34.9 & 18.5 \\
\hline I & 6 & 37.8 & 36.6 & 25.6 \\
\hline II & 5 & 39.4 & 34.4 & 26.2 \\
\hline III & 6 & 38.6 & 35.1 & 26.3 \\
\hline IV & 9 & 38.4 & 34.6 & 27.0 \\
\hline
\end{tabular}

and indirectly connected with it the lowest growth coefficient in the whole material (Table 7 and 8). This applies, although to a lesser degree, to the talus in males. Consequently the percentage formed by the talus of the torsal structure in postembryonic development decreases successively from group 0 to group IV (Table 14), whereas the percentages formed by the other bones increase. All the tarsal bones are larger in males than in females, the only exception being talus and os tarsale I in group 0. 
The bones of basipodium posterius in males increase their mass to a greater extent during postembryonic life than those of the metapodium, but less than the acropodium (Table 8). In females, on the other hand, this part of pes is distinguished by the lowest growth coefficient.

The tarsus forms the largest percentage of the skeletal structure of the pes (Table 10), but this decreases during the animal's life in favour of the more rapidly growing acropodium.

\subsection{Metapodium-ossa metatarsi}

The mass of os metatarsale $I I I+I V$ in group 0 is slightly greater in females than in males, whereas in the other groups these bones are decidedly larger in males (Table 3). In males this part of the pes, in comparison with the other two parts, has the lowest growth coefficient (Table 8), while in females this coefficients $i$ greater than the growth coefficient of the tarsal bone and smaller than for the skeleton of the digits.

The percentage of the metapodium in the structure of the pes has a tendency to decrease in males, but in females in maintained on a more or less uniform level. This percentage is greater in both sexes than that of the acropodium, but smaller than that of the basipodium (Table 16).

\subsection{Acropodium - ossa digiti pedis}

The greatest mass among the three phalanges of the pes is exhibited in both sexes by phalanx proximalis (Table 4). Phalanx media comes nex in order in all females, whereas in males this phalange occupies the second place only in groups $0-\mathrm{I}$, and in the other groups phalanx distalis comes second. The third phalange in order of mass is phalanx distalis in females, but in males it occupies third place only in groups 0 - I, and in the other groups phalanx media comes third.

Phalanx distalis is distinguished by a far greater growth coefficient in both sexes. Phalanx proximalis comes second in this order, and phalanx media third (Table 8).

Percentage increases in mass of the various bony components of the digitus pedis are, generally speaking, greater in the first two groups of males than of females, whereas the reverse is the case in the two oldest groups (Table 10).

The percentage formed by phalanx proximalis and phalanx media of the structure of the bony framework of digits exhibit tendencies to decrease during the animal's lifetime, whereas the percentage formed by phalanx distalis constantly increases (Table 13). 
In all the digital bones of pes are distinguished by a higher growth coefficient than the metatarsal bones and the tarsal bones (Table 8). Their percentage in the structure of the pes is the smallest, as compared with the tarsal and metatarsal bones (Table 16), and this percentage increases considerably during the postembryonic life of European bison.

\section{DISCUSSION}

The bones of the autopodial parts of the extremities in European bison are subject to continual variations in their mass, mainly progressive, but not infrequently regressive also. The factor causing and directing the development process of the skeleton of the extremities consists primarily of the skeleton muscles, and also the habitat in which the organism lives. This applies particularly to the ground which, if it influences the form of the skeleton of the extremities at all, does so primarily in respect of their autopodial parts. In the case of the bones of the basipodium an important factor in shaping their size relations is their position in relation to each other, which allows some of them only a very narrow space, while others are permitted to develop freely. The conclusion to be drawn from this is that the greater the ratio of the articular surface to the total surface of the given bone of the basipodium, the smaller its increases in mass. The nervous-humoral system, increasing body weight with increasing age, indispositions of the organism, physiological states such as gestation, food value etc. affect the whole of the ossification processes taking place during the individual's postembryonic life.

The proportions of the carpal bones are not constant during growth processes, the ridect cause of this being the different growth rate of the various components of the skeleton of the carpus. Os carpi accessorium is the most intensively growing bone. This intensive growth can be explained by its different situation and specific role. On account of its lateral position os carpi accessorium is not included in the formation of any of the rows of the carpal joints and consequently is not subjected to "cramped space " and increasing pressure as body weight increases, and this permits of its free development. In addition this bone is considered as the sesamoid bone serving two carpal muscles-m. flexor carpi ulnaris and $m$. extensor carpi ulnaris ( $\mathrm{S}$ w i èzy ńs ki, 1962; R ad o m ski, 1972). It is known ( $\mathrm{K}$ o c h, 1932; J a nicki, 1938; Empel \& Roskosz, 1963; Kobryńczuk, 1972) that the sesamoid bones, as the accessory structures associated with the muscles, are stimulated by them to intensified growt. Studies on the accessory carpal bone confirm that this is the case. The effects of the action of flexor carpi 
ulnaris and extensor carpi ulnaris are transferred by ligaments ( $\mathrm{R}$ adomski, 1972) to the ulnar carpal bone also and it is in this that we must find the explanation for its fairly intensive postembryonic development.

In all the carpal bones increase their bulk up to the end of the animals life, and their development rate is slower than that on the acropodium, but more intensive than that of the metapodium. $\mathrm{Koch}$ (1932) and J a nicki (1938) state that linear measurement of the carpal bones, as short bones, confirm that they increase their mass to a lesser degree during postembryonic life than long bones, and therefore this applies to the metacarpal bones. This is not, however, confirmed by our observations.

The metacarpal bones of males and females are characterized by considerable disproportion in the growth coefficients (Table 7). In males these bones increase their mass by 4 times as much during the animals life, whereas in females increase is only 2.7 times as much, that is, 1.5 times less than in males. This character of sexual dimorphism revaled by linnear measurements is unanimously confirmed by $\mathrm{J}$ anicki (1938) and Empel \& Roskosz (1963).

Among the phalanges of the manus it is always the one situated more peripherally which is characterized by greater growth rate, and thus the influence of the ground on ossification of the digital skeleton would appear very evident.

Bojanus (1827) considers that phalanx media is the smallest throughout the whole of an European bison's life. Our studies confirm this observation, but only in bison over 4 years old, whereas phalanx distalis is the smallest in the two groups of the youngest animals ( 0 and I) of both sexes.

No such distant sexual differences in growth coefficients as in the case of the fibular tarsal bone were ever observed among any of the bones in the material examined (Table 7 and 8). In males this bone increases its mass during the life span by over twice as much as in females. Consequently it grows most intensively of all the tarsal bones in males, but in females it comes next to last before the tibial tarsal bone, in order of increase in mass. It must be assumed that these disproportions are due to the difference between the sexes in rate of growth of corpus calcanei and to the fact that the body of this bone, which is the terminal place of insertion of tendo Achillei, is more strongly developed in the oldest males than in females of corresponding age. Thus the size of corpus calcanei would be the exponenital of the values of body weight and strength of the muscle extending the hock joint. As the weight of an adult male is far greater than that of an 
adult female (P y te l, 1969), then the lever formed by corpus calcanei must be of suitable bulk to deal with resistance moments and it is this which must be considered as the cause of the stronger development of the bone in males.

The growth coefficient of the tibial tarsal bone is the smallest recorded for the whole material (Table 7 and 8), and therefore this bones increases its mass during the animal's lifetime to the least degree. Similar conclusions, using linear measurements, were reached by Empel \& Ros$\mathrm{kosz}$ (1963). The cause of this state of affairs must be the cramped localization of this bone, the relatively large area of its articular surface (Kobryńczuk, 1972) not permitting of expansion of bone tissue in a direction from the surface, and the absence on it of insertions of the larger muscles (apart from $m$. extensor digitorum brevis, Ś wi eżyń$\mathrm{sk} \mathrm{i,} \mathrm{1962)} \mathrm{stimulating} \mathrm{the} \mathrm{bone} \mathrm{to} \mathrm{development.}$

The metatarsal bones in males, as in the cause of metapodium anterius, are distinguished by a far greater growth coefficient than in females.

The smallest phalanx of the pes in females is always phalanx distalis. It is also always the smallest in males, but only in the first two groups, whereas phalanx media is the smallest in the older groups. It is therefore only in the last case that our observations agree with those of $\mathrm{Boja}$ nus (1827), who stated that phalanx media is the smallest irrespective of sex and age. Among the phalanges of the pes phalanx media is characterized by the smallest growth coefficient, and phalanx distalis by the greatest, and therefore the rule does not apply here, as it does in the digits of the manus, that the more peripheral the situation of the given phalanx, the greater its growth coefficient.

To conclude this section it is necessary to consider the size ratios of the subsegments of the manus and the pes corresponding to each other, their growth rate, the percentages they form of the structure of the autopodium, etc.

The carpus in males increases its mass 1.3 times more than does the tarsus, and in females this index is even greater - 2.0. While the carpal bones in males increase their mass by 1.2 times more than in females, when the tarsal bones of the two sexes are compared, this relation is even greater, being 1.8, showing that the bones of the basipodium anterius are characterized by a greater degree of growth than the corresponding sub-segment of the pelvic limb. Sexual differences due to the greater growth rate are, however, far more distinct in basipodium posterius than anterius.

In the youngest males the skeleton of the tarsus is 3.6 times larger than the skeleton of the carpus. In the oldest group of males the tarsus is only 2.7 times greater than the carpus. In the youngest group of 
females the tarsus is as much as 5.8 times greater than the carpus, whereas in the group of oldest females this index is only 3.0. Therefore if the tarsal bones do not grow as intensively as the carpal bones during postembryonic development, this applies in a greater degree to females.

The carpal bones in both sexes increase the percentage they form of the skeleton of the manus during the animals' lifetime (this can be seen more clearly in females). In turn the tarsal bones in European bison decrease their participation in the structure of the pes during posternbryonic life, and to a more marked degree in females. It can thus be seen that the carpal bones in females are more progressive in their development than the bones of this sub-segment in males, and to almost the same degree the tarsal bones in females are more regressive than in males.

The metatarsal bones in the youngest individuals of both sexes are 1.2 times greater than the metacarpal bones. This ratio changes with age in favour of the metacarpus, and in the oldest males is $1: 1.1$, and in females $1: 1.2$. Irrespective of age and sex the bone mass of the metapodium anterius is always smaller than metapodium posterius. The metacarpal bones come closer in respect of mass to the metatarsal bones in older animals, in males to a greater degree than females. This is due to the metacarpal bones increasing in males during postembryonic life 1.2 times more than the metatarsal bones, and in the case of females only 1.0 times more. The bones of the metapodial parts form a lesser percentage of the corresponding autopodia. In the case of the metacarpal bones decrease in percentage is $7.5 \%$ in males and $11.1 \%$ in females. In turn during the animals' life time the metatarsal bones lose $4.1 \%$ in males, but only $0.3 \%$ in females, of the part they formed of the skeleton of the pes. It is clear from this that the metacarpal bones "regress « from the part they play in the skeleton of the manus to a greater degree in females than in males. The reverse is the case in relation to the metatarsal bones. In females their percntage in the structure of the pes is almost uniform throughout the animals' life, while losses in this respect are greater in males. It must be gathered from this that despite the fact that growth coefficients are higher for the metacarpal bones than for the metatarsal bones, yet in relation to their components of the skeleton of the autopodium the latter bones are more progressive, particularly in males.

Except for a small number of casses the mass of the various phalanges of the manus is greater than the mass of the phalanges of the pes corresponding to them.

The skeleton of the digit of the manus in males increases its mass by 1.2 times more than the skeleton of the digit of the pes. In females the 
corresponding ration of growt coefficients was only 1.1. The percentage formed by the digital skeleton of the structure of the skeleton of the manus increases during the life-time of males by $6.7 \%$, and by $8.3 \%$ in females. The corresponding percentage formed by digits of the structure of the pes increases in males by $5.9 \%$, and in females by $8.5 \%$.

With the exception of the youngest group of animals the skeleton of autopodia in males is always greater than in females, this being more distinctly manifested when comparison is made with the anterior autopodia. In all European bison the skeleton of the pes is always greater that the skeleton of the manus, and these disproportions are far graeter in young animals.

In conslusion it must be said that the bones of the autopodia of the extremities in males exhibit far greater growth rate in young animals than in the case with females, but in males over 12 years old the bones exhibit practically no tendency to growth, whereas in females intensivity of these processes can still be observed.

\section{REFERENCES}

1. Bojanus L. H., 1872: De uro nostrate eiusque sceleto commentatio. Nov. Acta Akad. Leopold. Carol., 13: 411-478. Bonnae.

2. Davletova L. V., 1960: The growth of digestion organs in the cource of ontogenesis in sheep. Bul. Mosk. Obšč. Isp. Prirody Otd. Biol., 65, 2: 107-119. [In Russian with English summ.]

3. Duerst J. U., 1926: Vergleichende Untersuchungsmethoden am Skelett bei Säugern. (Abderhalden: Handbuch d. biol. Arbeitsmeth.), 7: 125-530. Urban u. Schwarzenberg. Berlin - Wien.

4. Empel W., 1962: Morphologie des Schädels von Bison bonasus (L in na e us 1758). Acta theriol., 6, 4: 53-111.

5. Empel W. \& Roskosz T., 1963: Das Skelett der Gliedmassen des Wisents, Bison bonasus (L i n n a u s, 1758). Acta theriol., 7, 13: 259-300.

6. J a nicki S., 1938: Badania nad szkieletem żubra (Bison bonasus L.). Prace Roln.-Leśne P.A.U., 27: 1-55.

7. Juśko J., 1953: Dymorfizm płciowy szkieletu żubra (Bison bonasus). Folia morphol., 4, 1: $1-30$.

8. Kobryń H., 1973: The thorax in European bison and other ruminants. Acta theriol., $18, \ldots$.

9. Kobry íczuk F., 1972: Budowa połączeń kości w kończynach miednicznych żubra (Bison bonasus L.) w rozwoju postnatalnym. Diss., Agricult. Academy, Warszawa.

10. Koch W., 1932: Über Wachstums- und Altersveränderungen am Skelett des Wisents. Abh. Mat.-naturw. Abt., Bayer. Akad. Wiss. Supl.-Bd., 15 Abh.: 555 $-678$.

11. Nomina Anatomica Veterinaria, 1968. Vienna.

12. Pytel S. M., 1969: Morphology of digestive tract of the European bison. Acta theriol., 14, 27: $349-402$. 
13. Ra domski L., 1972: Stawy kończyn piersiowych żubra, Bison bonasus (L.), w rozwoju postnatalnym. Diss., Agricult. Academy, Warszawa.

14. Roskosz T., 1962: Morphologie der Wirbelsäule des Wisents, Bison bonasus (Li nn a e u s, 1758)). Acta theriol., 6, 5: 113-162.

15. Roskosz T., Kobryńczuk F. \& Kobryń H., 1966: Hydrometrische Bestimmung der Wirbelgrösse beim Rothirsch. Acta theriol., 11, 8: 281-288.

16. Roskosz T., 1972: Określanie wielkości żubra, Bison bonasus (L i n n a u s, 1758), na podstawie osteometrii odcinków metapodialnych. Zeszyty Naukowe SGGW, Wet., 2: 39-47.

17. Sokolov I. I., 1971: Postkranialnyj skelet predstavitelej roda Bison. Trudy Zool. Inst. Akad. Nauk SSSR, 48: 198-219.

18. Sw i ė̇y ń ski K., 1962: The skeletal musculatural system of the European bison, Bison bonasus (Linn a e u s 1758). Acta theriol., 6, 6: 165-218.

19. Żabiński J. [Ed.], 1947-65: Pedigree book of the European bison. 1-370. Państw. Wyd. Nauk., Warszawa.

Accepted, March 15, 1973.

Institute of Animal Physiology,

Agricultural Academy,

Grochowska 272, 03-849 Warszawa, Poland.

Franciszek KOBRYÑCZUK i Henryk KOBRYN

POZAPEODOWY WZROST KOSCI ODCINKOW AUTOPODIALNYCH KOŃCZYN
ŻUBRA

Streszczenie

Prześledzono rozwój pozapłodowy kości odcinków autopodialnych kończyn 70 żubrów obu płci. W badaniach wykorzystano hydrometryczną próbę określania wielkości kości. Stwierdzono, że kości odcinków autopodialnych u żubra podlegają w trakcie rozwoju pozapłodowego ciągłym zmianom. Zmiany te mają najczęściej charakter progresywny, nierzadko także regresywny. Na ich występowanie, poza wiekiem żubrów, m. in. wpływa umięśnienie szkieletowe i sąsiedztwo topograficzne poszczególnych jednostek kostnych. Zdecydowana większość kości samców posiada większą objętość niż odpowiadające im kości samic. Ponadto kości samców w okresie do 12 lat rosną intensywniej niż kości samic. Z kolei u samców w wieku powyżej 12 lat przyrost masy kostnej jest minimalny, podczas gdy u samic jest on jeszcze dość znaczny. 